\title{
CLINICAL SUPERVISION TO IMPROVE THE ABILITY OF CLASS V TEACHERS ELEMENTARY SCHOOL IN COOPERATIVE LEARNING MODEL
}

\section{SUPERVISI KLINIS UNTUK MENINGKATKAN KEMAMPUAN GURU KELAS V SEKOLAH DASAR DALAM MODEL PEMBELAJARAN KOOPERATIF}

\author{
Kamat \\ Dinas Pendidikan Kabupaten Bengkulu Utara, Bengkulu \\ Email: hapdea@gmail.com
}

Received 14 Januari 2020, Revised 30 Februari 2020, Accepted 30 April 2020

\begin{abstract}
This research reveals the teacher's low ability in preparing Classroom Action Research Proposals (CAR). This proved to be the absence of teachers who submitted classroom action research proposals in the last 2 years. This study aims to determine the extent of the effectiveness of the application of group guidance in an effort to improve teacher competence in the preparation of CAR proposals. This research was carried out in the guiding process at the regular meeting of Subject Teachers at Neger 06 Seluma Middle School. The School Action Research is conducted in two cycles, where each cycle has four stages, namely planning, implementation, observation and reflection. The results in the study are: 1). The indicator of success in the study is: if $>10 \%$ of the number of coaching participants have obtained an average value of $\geq 85,2)$. cycle II obtained supervisor observation data (4.22), teacher observation (4.14), classical work results (84.02). Indicators of success have exceeded School Action Research declared successful. 3). Very effective group guidance in an effort to improve competency in the preparation of CAR proposals reaching $90 \%$ of the total number of participants has succeeded in developing CAR proposals as expected.
\end{abstract}

Keywords: Group Guidance, competence, CAR

\begin{abstract}
Abstrak
Penelitian menidentifikasi kemampuan guru dalam menyusun Proposal Penelitian Tindakan Kelas (PTK). Hal ini terbukti tidak adanya guru yang mengajukan proposal penelitian tindakan kelas dalam 2 tahun terakir. Penelitian ini bertujuan untuk mengetahui sejauh mana efektifitas penerapan bimbingan kelompok dalam upaya meningkatkan kompetensi guru dalam penyusunan proposal PTK. Penelitian ini dilaksnaakan dalam proses bimbinganya pada pertemuan rutin Musyawarah Guru Mata Pelajaran (MGMP) di SMP Negerl V Bengkulu Utara. Pelaksanaan Penelitian Tindakan Sekolah (PTS) ini sebanyak dua siklus, dimana masing-masing siklus terdapat empat tahapan yaitu perencanaan, pelaksanaan, observasi dan refleksi. Hasil dalam penelitian adalah : 1). Indikator keberhasilan dalam penelitian adalah : jika $\geq 10 \%$ dari jumlah peserta pembimbingan telah memperleh nilai ratarata $\geq 85,2$ ). siklus II diperoleh data observasi pengawas $(4,22)$, observasi guru $(4,14)$, hasil kerja secara klasikal $(84,02)$. Indikator keberhasilan telah terlampaui Penelitian Tindakan Sekolah (PTS) dinyatakan berhasil. 3). Bimbingan kelompok sangat efektif dalam upaya meningkatkan kompetensi dalam penyusunan proposal PTK mencapai $90 \%$ dari jumlah peserta telah berhasil menyusun proposal PTK sesuai harapan.
\end{abstract}

Kata Kunci : Bimbingan Kelompok, kompetensi, PTK 


\section{A. Pendahuluan}

Berdsarkan hasil supervisi yang telah dilaksanakan oleh peneliti dari sebelas guru kelas $\mathrm{V}$ di enam SD binaan, ternyata rata-rata guru belum mampu melaksanakan model pembelajaran kooperatif secara maksimal. Dari hasil supervisi rutin dapat dilihat secara nyata bahwa guru kelas $\mathrm{V}$ masih melaksanakan pembelajaran yang biasa-biasa saja. Pembelajaran yang dilakukan hanya menggunakan metode ceramah tanpa ada variasi dan kurang memanfaatkan peluang, membentuk kelompok kelompok kecil di kelasnya.

Kegiatan pembelajaran di Enam SD binaan masih tergolong rendah dan kemampuan guru kelas $\mathrm{V}$ dalam mengajar belum berpusat pada model pembelajaran kooperatif secara optimal. Terdapat bukti prestasi para peserta didik kelas $\mathrm{V}$ masih rendah belum sesuai dengan harapan lembaga sekolah orang tua dan masyarakat. Dalam melaksanakan supervisi, Pengawas Sekolah melihat juga aktifitas Kepala Sekolah yang ternyata mereka belum berupaya mengubah strategi supervisinya terhadap guru guru di kelas. Supervisi oleh Kepala Sekolah yang dilakukan masih terkesan rutinitas belaka belum melakukan pendekatan-pendekatan baru dan belum melaksanakan tindak lanjut secara serius terutama pada teknik-teknik model pembelajaran kooperatif.

Frekuensi pelaksanaan supervisi oleh Kepala Sekolah juga belum optimal. Dari data supervisi dapat dilihat dalam satu bulan supervisi yang dilakukan, ratarata tidak lebih dari 1 kali atau 4,17\% sedangkan sisa waktunya sebanyak 95,83\% lebih banyak digunakan untuk melaksanakan tugas di kantor Sekolah atau melaksanakan tugas-tugas lain terkait tugas kepala sekolah. Supervisi yang dilakukan masih terkesan melaksanakan pemantauan saja, seolaholah hanya melihat dokumen dan hanya memotret keadaan saat terjadi di sekolah tanpa ada tindakan yang nyata menuju perbaikan pembelajaran selanjutnya. Oleh sebab itu di samping pemantauan harusnya juga melalui pengamatan yang cermat dalam proses pembelajaran, sehingga dapat ditemukan hal-hal yang perlu ditingkatkan dan dikembangkan oleh sekolah itu sendiri.

Kondisi ini peneliti sebagai Pengawas Sekolah berupaya agar semua guru dalam melaksanakan pembelajaran berpusat dengan model pembelajaran kooperatif, sesuai dengan ketentuan yang ada dalam standar proses dalam Permendikbud nomor 22 tahun 2016. Ketentuan itu merupakan pedoman yang harus diwujudkan dalam proses pembelajaran oleh guru yang merupakan pimpinan di kelas itu. Apabila semua guru dalam melaksanakan tugasnya setiap hari mengajar dengan berpusat kooperatif di kelasnya, maka dapat dikatakan bahwa hasil dari proses pembelajaran itu akan tercapai memuaskan, yang pada gilirannya akan meningkatkan prestasi belajar para peserta didiknya.

Kemampuan guru dalam melaksanakan model pembelajaran kooperatif melalui supervisi klinis oleh pengawas sekolah dan kepala sekolah, dengan bimbingan arahan kesadaran tinggi diharapkan para guru dapat melakukan pembelajaran bermutu, sehingga berpengaruh positif terhadap perilaku peserta didik dan menambah kemajuan prestasi belajar mereka. Kemampuan dan keterampilan para guru

Available online at : http://journal.pdmbengkulu.org/index.php/semar 
dalam menyusun rencana pelaksanaan Model Pembelajaran kooperatif yang baik, yang selanjutnya proses pembelajaran akan dapat tepat sasaran, dan target materi dalam Standar Kompetensi dan Kompetensi Dasar dapat dicapai. Selain itu juga kreatif membentuk kelompok-kelompok kecil dalam pembelajaran yang dapat menumbuhkembangkan motivasi dan semangat belajar anak. Untuk selanjutnya mampu menumbuhkembangkan kreatifitas peserta didik serta berikutnya pembelajaran dapat bermakna. Hal ini akan mewarnai kegiatan belajar dalam meningkatkan prestasinya sehari-hari. Dengan demikian kemampuan dan keterampilan guru perlu dibimbing yaitu dalam mewujudkan model pembelajaran kooperatif yang sesuai dengan visi, misi sekolah yang telah dirumuskan.

Kegiatan supervisi klinis yang dilakukan Pengawas Sekolah sebagai peneliti akan berupaya mempengaruhi guru selalu termotivasi, dan mereka agar selalu merasa sebagai agen pembelajaran yang sesuai dengan ketentuan. Pengawas Sekolah sebagai peneliti melakukan supervisi klinis dengan terprogram dan selalu berupaya meningkatkan kemampuan guru untuk melaksanakan pembelajaran dengan tertib dan baik. Apabila supervisi sudah dilaksanakan secara rutin, terprogram dan berkelanjutan sesuai dengan prosedur ketentuan yang ada, maka dapat diharapkan guru lebih mampu untuk melaksanakan Model Pembelajaran kooperatif yang baik berkualitas serta mampu mengubah perilaku peserta didik untuk lebih aktif belajar, yang pada gilirannya mampu mencapai kemajuan prestasi belajar yang lebih baik.

Untuk memecahkan masalah yang ada di enam SD binaan, perlu adanya tindakan khusus yang dilakukan oleh pengawas sekolah yang berkolaborasi dengan masing-masing kepala sekolah SD binaan, yaitu: Penerapan supervisi klinis untuk meningkatkan kemampuan guru kelas V Sekolah Dasar dalam model pembelajaran kooperatif di enam SD binaan Semester I Tahun Pelajaran 2018/2019. Tindakan tersebut dilakukan melalui supervisi klinis secara individu di masing-masing guru kelas.

Dalam hal ini Pengawas Sekolah sebagai peneliti ingin meningkatkan keterampilan dan kemampuan guru dalam melaksanakan model pembelajaran kooperatif. Termasuk kemampuan Guru dalam penyusunan Rencana Pelaksanaan Pembelajaran yang matang dengan mencantumkan sumber bahan, sarana dan alat peraga yang bervariasi, maupun peralatan/media dalam proses pembelajaran yang menarik perhatian peserta didik. Pemilikan RPP yang baik bagi guru juga akan mempengaruhi lancarnya penyajian pembelajaran di kelasnya.

\section{B. Metode Penelitian Subjek Penelitian}

Lokasi tempat untuk melakukan penelitian tindakan sekolah ini adalah di sekolah Dasar Negeri di enam SD binaan. Hal ini dikarenakan Sekolah Dasar di enam SD binaan tersebut merupakan sekolah yang berada di daerah binaan peneliti selaku Pengawas Sekolah SD Inti. Sedangkan waktu penelitian direncanakan pada tanggal 23 Juli sampai 10 November 2018.

Subjek penelitian adalah guru kelas $\checkmark$ Sekolah Dasar di enam SD binaan sebanyak 11 orang guru, yang berdasarkan hasil supervisi rutin, guruguru tersebut masih memiliki kemampuan yang rendah belum maksimal dalam melaksanakan model pembelajaran kooperatif. Adapun data nama kepala sekolah dan nama guru kelas $V$ enam SD binaan adalah sebagai berikut:

Tabel 1. Data nama kepala sekolah dan nama guru kelas $V$ enam SD binaan.

\begin{tabular}{|l|lc|}
\hline $\begin{array}{c}\text { Nama SD Binaan/ } \\
\text { Kepala Sekolah }\end{array}$ & \multicolumn{2}{|c|}{ Nama Guru Kelas } \\
\hline \hline $\begin{array}{l}\text { SDN 006 } \\
\text { Bengkulu Utara } \\
\text { Drs. Sunarmo }\end{array}$ & $\begin{array}{l}\text { 1) Tigor } \\
\text { Tumorang, S.Pd }\end{array}$ & $5 a$ \\
\cline { 2 - 3 } & \begin{tabular}{l} 
2) $\begin{array}{l}\text { Ainun Jariah, } \\
\text { S.Pd }\end{array}$ \\
\hline
\end{tabular} \\
\hline
\end{tabular}




\begin{tabular}{|c|c|c|}
\hline & 3) Suparso, S.Pd & $5 c$ \\
\hline $\begin{array}{l}\text { SDN } 011 \\
\text { Bengkulu Utara } \\
\text { Januarto, S.Pd }\end{array}$ & 4) Marlinti & 5 \\
\hline \multirow{2}{*}{$\begin{array}{l}\text { SDN } 128 \\
\text { Bengkulu Utara } \\
\text { Relina Septisiah, } \\
\text { S.Pd }\end{array}$} & $\begin{array}{l}\text { 5) Abdul Aziz, } \\
\text { S.Pd }\end{array}$ & $5 a$ \\
\hline & 6) Enisfa, S.Pd & $5 b$ \\
\hline \multirow{3}{*}{$\begin{array}{l}\text { SDN } 166 \\
\text { Bengkulu Utara } \\
\text { Kasidin, S.Pd }\end{array}$} & $\begin{array}{l}\text { 7) Yeci Karlina, } \\
\text { S.Pd } \\
\end{array}$ & $5 a$ \\
\hline & $\begin{array}{l}\text { 8) Lusi Kurnia, } \\
\text { S.Pd }\end{array}$ & $5 b$ \\
\hline & 9) Haryani, S.Pd & $5 c$ \\
\hline $\begin{array}{l}\text { SDN } 170 \\
\text { Bengkulu Utara } \\
\text { Eldawati, S.Pd }\end{array}$ & $\begin{array}{l}\text { 10) Supriyadi, } \\
\text { S.Pd }\end{array}$ & 5 \\
\hline $\begin{array}{l}\text { SDS Muh. Arga } \\
\text { Makmur } \\
\text { Poniyem, S.Pd }\end{array}$ & $\begin{array}{l}\text { 11) } \\
\text { Anisah, S.Pd }\end{array}$ & 5 \\
\hline
\end{tabular}

Tabel 2. Jadwal Penelitian Tindakan Sekolah

\begin{tabular}{|l|l|}
\hline \multicolumn{1}{|c|}{ Kegiatan } & Rencana Pelaksanaan \\
\hline $\begin{array}{l}\text { Penyusunan } \\
\text { proposal }\end{array}$ & Tgl. 2 s.d. 21 Juli 2018 \\
\hline $\begin{array}{l}\text { Penyusunan } \\
\text { Instrumen }\end{array}$ & $\begin{array}{c}\text { Tgl. 23 Juli s.d. 4 } \\
\text { Agustus 2018 }\end{array}$ \\
\hline $\begin{array}{l}\text { Pengumpulan } \\
\text { data }\end{array}$ & $\begin{array}{l}\text { Tgl. 6 Agustus s.d } 8 \\
\text { Oktober 2018 }\end{array}$ \\
\hline Analisis Data & $\begin{array}{l}\text { Tgl. 9 s.d 31 Oktober } \\
2018\end{array}$ \\
\hline $\begin{array}{l}\text { Penyusunan } \\
\text { laporan }\end{array}$ & $\begin{array}{c}\text { Tgl. 1 s.d 10 Nopember } \\
\text { 2018 }\end{array}$ \\
\hline
\end{tabular}

\section{Tindakan}

Tindakan yang dilakukan adalah supervise klinis yang dilakukan secara bertahap; siklus I supervise dilakukan menggunakan supervisi klinis secara berkelompok, kemudian siklus II dilakukan menggunakan supervisi klinis secara individual yang terdiri dari tahap perencanaan, pelaksanaan tindakan, pengamatan/observasi dan refleksi.

Rancangan tindakan dilakukan dengan prosedur penelitian berdasarkan pada prinsip Kemmis dan Taggart (1988) yang mencakup kegiatan sebagai berikut:

perencanaan

(planning), (2) pelaksanaan tindakan (action), 3) observasi (observation), (4) refleksi (reflection) atau evaluasi. Keempat kegiatan ini berlangsung secara berulang dalam bentuk siklus.

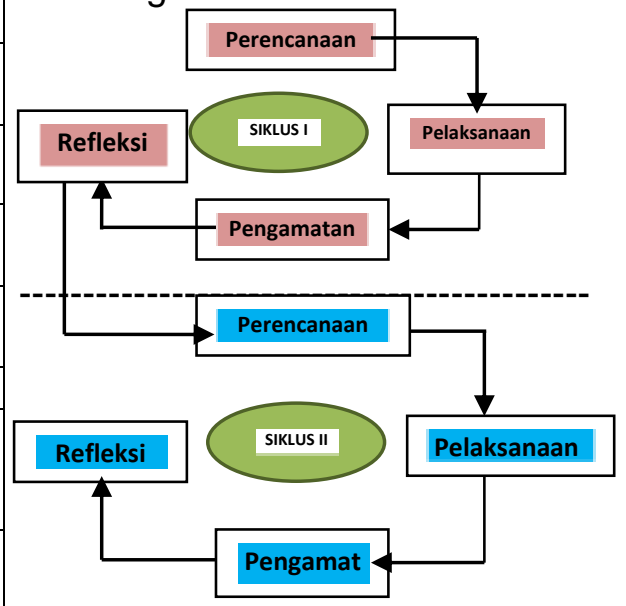

Gambar 1. Desain Penelitian Tindakan Sekolah

\section{Teknik Pengumpulan Data}

Data awal penelitian ini adalah berupa hasil supervisi secara rutin dari peneliti sebagai Pengawas Sekolah, serta data akhir diperoleh melalui observasi, dokumentasi dan pengisian lembar instrumen penelitian.

\section{Instrumen Penelitian}

Instrumen penelitian berupa lembar observasi dan lembar penilaian, yang berguna untuk mencatat semua peristiwa dalam pembimbingan Model Pembelajaran Kooperatif pada guru kelas $V$ SD di enam SD binaan dan pelaksanaan tugas guru dalam pembelajaran selama penelitian berlangsung. Kegiatan observasi adalah mengamati aktivitas peserta pembimbingan Model Pembelajaran Kooperatif pada guru kelas V SD di enam SD binaan dengan menggunakan lembar observasi yang telah disiapkan dan dilakukan oleh teman sejawat.

\section{Teknik Analisa Data}

Analisis data yang digunakan peneliti dengan menggunakan analisis deskriptif komparatif, yaitu dengan membandingkan pelaksanaan pembelajaran pendekatan kooperatif sebelum dilaksanakan supervisi klinis, dan pembelajaran sesudah dilakukan supervisi klinis. 
Selanjutnya dari hasil nilai kemampuan melaksanaan pembelajaran kooperatif sebelum dilaksanakan supervisi klinis dibandingkan dengan hasil sesudah dilaksanakan supervisi klinis untuk mengetahui kemajuan hasil yang dicapai dalam tampilan kemampuan kinerja guru di kelasnya.

\section{Hasil Penelitian Dan Pembahasan Hasil Penelitian \\ Kondisi Awal atau Pra Tindakan}

1. Kemampuan guru dalam melakukan proses Model Pembelajaran kooperatif ;

Kondisi awal kemampuan guru dalam melakukan proses Model Pembelajaran kooperatif masih rendah belum maksimal. Adapun sebagai subjek penelitian yaitu guru kelas V Sekolah Dasar di enam SD binaan sebagai daerah binaan peneliti. Dari hasil supervisi yang dilakukan peneliti, diperoleh data guru-guru tersebut belum memiliki kemampuan maksimal dalam melaksanakan pembelajaran berpusat kooperatif. Dari 11 orang guru yang termasuk kategori masih kurang hanya 7 orang dan 4 orang lainya dalam kategori cukup. Untuk itu peneliti akan melakukan tindakan agar semua guru mampu melaksanakan pembelajaran kooperatif secara maksimal.

Begitu pula supervisi yang dilakukan peneliti belum maksimal, karena itu Pengawas Sekolah sebagai peneliti berupaya melakukan tindakan kegiatan. Hal ini tampak dalam tabel 5, bahwa guru berkode $\mathrm{A}$ adalah kelompok guru kelas $\mathrm{V}$ yang termasuk dalam kategori kurang, sedangkan guru yang berkode $B$ adalah kelompok guru kelas $\mathrm{V}$ yang masuk kategori cukup, namun masih dalam batas bawah. Rata-rata skor untuk kelompok guru A (kategori kurang) dan $\mathrm{B}$ (kategori cukup) adalah 50 dan 59 ratarata keduanya adalah 55 termasuk kategori kurang batas maksimum mampu melaksanakan model pembelajaran kooperatif karena skor maksimal 100, dengan rincian skor 0 s.d 49 termasuk kategori kurang, 50 s.d 75 kategori cukup, 76 s.d. 90 kategori baik dan 91 s.d. 100 kategori sangat baik (tampak dalam tabel.6).

Guru melakukan pengelolaan model pembelajaran kooperatif tampak kurang maksimal. Belum banyak muncul skor 3 atau skor yang terpenuhi, berarti belum ada yang nampak baik. Mereka hanya mengajar menggunakan buku teks yang dimiliki tanpa memperhatikan silabus dan RPP. Metode yang digunakan hanya ceramah tidak bervariasi dan tugas mengerjakan soal saja. Salah satu guru belum menggunakan alat peraga, sedangkan guru yang menggunakan alat peraga tersebut belum maksimal. Perbaikan dan pengayaan juga belum dilakukan dengan baik.

Tabel 3. Rata-Rata Pra Siklus Tentang Model Pembelajaran Kooperatif

\begin{tabular}{|c|c|c|c|c|}
\hline NO & INDIKATOR & $\begin{array}{c}\text { Kel A } \\
\text { (kura } \\
\text { ng) }\end{array}$ & $\begin{array}{l}\text { Kel B } \\
\text { (cuku } \\
\text { p) }\end{array}$ & $\begin{array}{c}\text { Rat } \\
\text { a- } \\
\text { rat } \\
\text { a }\end{array}$ \\
\hline \multirow[t]{5}{*}{ I } & $\begin{array}{l}\text { Metode dan } \\
\text { pengelolaan } \\
\text { Kelas }\end{array}$ & & & \\
\hline & $\begin{array}{l}\text { Pengelolaan } \\
\text { peserta didik } \\
\text { bervariasi }\end{array}$ & 2 & 3 & 3 \\
\hline & $\begin{array}{l}\text { Kegiatan } \\
\text { peserta didik } \\
\text { bervariasi }\end{array}$ & 2 & 3 & 2 \\
\hline & $\begin{array}{l}\text { Peran peserta } \\
\text { didik dlm } \\
\text { kelompok } \\
\text { kecil }\end{array}$ & 2 & 3 & 2 \\
\hline & $\begin{array}{l}\text { Kelompok } \\
\text { belajar } \\
\text { peserta didik } \\
\text { beragam }\end{array}$ & 2 & 3 & 2 \\
\hline \multirow[t]{2}{*}{ II } & $\begin{array}{l}\text { Ketrampilan } \\
\text { bertanya }\end{array}$ & & & \\
\hline & $\begin{array}{l}\text { Guru } \\
\text { memberi } \\
\text { kesempatan }\end{array}$ & 2 & 3 & 3 \\
\hline
\end{tabular}


Kamat

Supervisi Klinis Untuk Meningkatkan Kemampuan Guru...

\begin{tabular}{|c|c|c|c|c|}
\hline & peserta didik & & & \\
\hline & $\begin{array}{l}\text { Guru } \\
\text { mendorong } \\
\text { peserta didik } \\
\text { bertanya }\end{array}$ & 2 & 3 & 2 \\
\hline & $\begin{array}{l}\text { Peserta didik } \\
\text { berani } \\
\text { bertanya }\end{array}$ & 2 & 3 & 2 \\
\hline \multirow[t]{4}{*}{ III } & $\begin{array}{l}\text { Pelayanan } \\
\text { individual }\end{array}$ & & & \\
\hline & $\begin{array}{l}\text { Ada program } \\
\text { pengembang } \\
\text { an }\end{array}$ & 2 & 2 & 2 \\
\hline & $\begin{array}{l}\text { Penyelesaian } \\
\text { tugas peserta } \\
\text { didik }\end{array}$ & 2 & 3 & 3 \\
\hline & $\begin{array}{l}\text { Guru } \\
\text { melakukan } \\
\text { tindak lanjut }\end{array}$ & 2 & 2 & 2 \\
\hline \multirow[t]{4}{*}{ IV } & $\begin{array}{l}\text { Sumber } \\
\text { belajar dan } \\
\text { alat bantu }\end{array}$ & & & \\
\hline & $\begin{array}{l}\text { Gutu } \\
\text { menggunaka } \\
\text { n berbagai } \\
\text { sumber }\end{array}$ & 2 & 2 & 2 \\
\hline & $\begin{array}{l}\text { Guru } \\
\text { membuat alat } \\
\text { bantu }\end{array}$ & 2 & 3 & 2 \\
\hline & $\begin{array}{l}\text { Guru trampil } \\
\text { mengunakan } \\
\text { alat bantu }\end{array}$ & 2 & 3 & 2 \\
\hline \multirow[t]{4}{*}{$\mathbf{V}$} & $\begin{array}{l}\text { Umpan balik } \\
\text { dan } \\
\text { penilaian }\end{array}$ & & & \\
\hline & $\begin{array}{l}\text { Guru } \\
\text { memberi } \\
\text { umpan balik } \\
\text { menantang }\end{array}$ & 2 & 2 & 2 \\
\hline & $\begin{array}{l}\text { Guru } \\
\text { menggunaka } \\
\text { n berbagai } \\
\text { penilaian }\end{array}$ & 2 & 3 & 2 \\
\hline & $\begin{array}{l}\text { Guru } \\
\text { memberi } \\
\text { penghargaan }\end{array}$ & 2 & 2 & 2 \\
\hline \multirow[t]{3}{*}{ VI } & $\begin{array}{l}\text { Komunikasi } \\
\text { dan Interaksi }\end{array}$ & & & \\
\hline & $\begin{array}{l}\text { Penggunaan } \\
\text { bahasa guru }\end{array}$ & 2 & 2 & 2 \\
\hline & $\begin{array}{l}\text { Ada } \\
\text { komunikasi } \\
\text { antara guru } \\
\text { dan peserta }\end{array}$ & 2 & 2 & 2 \\
\hline
\end{tabular}

\begin{tabular}{|c|c|c|c|c|}
\hline & didik & & & \\
\hline \multirow[t]{3}{*}{ VII } & $\begin{array}{l}\text { Keterlibatan } \\
\text { peserta didik }\end{array}$ & & & \\
\hline & $\begin{array}{l}\text { Peserta didik } \\
\text { aktif dlm } \\
\text { pembelajaran }\end{array}$ & 2 & 2 & 2 \\
\hline & $\begin{array}{l}\text { Guru } \\
\text { memberi } \\
\text { kesempatan } \\
\text { kpd peserta } \\
\text { didik }\end{array}$ & 2 & 2 & 2 \\
\hline \multirow[t]{3}{*}{ VIII } & Refleksi & & & \\
\hline & $\begin{array}{l}\text { Guru } \\
\text { meminta } \\
\text { peserta didik } \\
\text { menulis } \\
\text { kesan }\end{array}$ & 2 & 2 & 2 \\
\hline & $\begin{array}{l}\text { Guru } \\
\text { melakukan } \\
\text { refleksi diri }\end{array}$ & 2 & 2 & 2 \\
\hline \multirow[t]{2}{*}{ IX } & Hasil Karya & & & \\
\hline & $\begin{array}{l}\text { Hasil karya } \\
\text { peserta didik } \\
\text { dipajang }\end{array}$ & 2 & 2 & 2 \\
\hline \multirow[t]{5}{*}{$\mathbf{X}$} & Hasil belajar & & & \\
\hline & $\begin{array}{l}\text { Hasil belajar } \\
\text { memenuhi } \\
\text { KKM }\end{array}$ & 2 & 3 & 2 \\
\hline & $\begin{array}{l}\text { Peserta didik } \\
\text { percaya diri } \\
\text { berani tampil }\end{array}$ & 2 & 2 & 2 \\
\hline & Jumlah skor & 50 & 59 & 55 \\
\hline & Kategori & $\begin{array}{c}\text { Kuran } \\
g\end{array}$ & $\begin{array}{l}\text { Cuku } \\
\mathrm{p}\end{array}$ & $\begin{array}{l}\text { Kur } \\
\text { an } \\
\text { q }\end{array}$ \\
\hline
\end{tabular}

Keterangan :

- Perolehan Kategori

skor 0 - Kurang (K)

55

- Perolehan Kategori skor 56 - $\quad$ Cukup (C)

75

- Perolehan Kategori Baik skor 76 - (B)

90

- Perolehan Kategori

skor 91 - Sangat Baik

100 (SB) 


\section{Supervisi oleh Pengawas Sekolah (peneliti)}

Supervisi yang dilakukan peneliti dalam hal ini adalah supervisi klinis yaitu pembinaan atau pembimbingan untuk pengelolaan pembelajaran yang mengarah pada perbaikan proses pembelajaran. Sebelumnya pembimbingan hanya dilakukan oleh peneliti pada waktu guru melaksanakan KKG yang diselenggarakan oleh Gugus Sekolah. Dengan demikian pembimbingan yang dilakukan Pengawas Sekolah sangat kurang. Dalam KKG Pengawas Sekolah melakukan pembinaan bersifat informatif dan secara klasikal, hampir belum pernah Pengawas Sekolah melakukan pembimbingan secara individu. Kegiatan KKG tersebut sangat tergantung kepada ketua Gugus Sekolah, dan sudah sewajarnya setiap ada jadwal KKG Pengawas Sekolah berperan menghadiri, membimbing secara klasikal di SD yang sesuai jadwal kegiatan KKG.

\section{Deskripsi Siklus 1 \\ Perencanaan Tindakan}

Beranjak dari proposal yang sudah tersusun, peneliti mempersiapkan materi untuk pembimbingan yaitu Permendikbud nomor 22 tahun 2016 tentang Standar Proses dan pedoman pengelolaan model pembelajaran kooperatif dari berbagai sumber. Materi ini diberikan kepada subjek penelitian. Standar Proses berisi aturan-aturan yang harus dilakukan guru dalam proses pembelajaran. Pedoman pengelolaan model pembelajaran kooperatif berisi tentang model-model pembelajaran dan pengelolaan kelas dalam melaksanakan model pembelajaran kooperatif yang harus dilakukan oleh guru. Peneliti melakukan koordinasi dengan Kepala Sekolah pada enam SD binaan tentang rencana tindakan pembimbingan dalam Penelitian Tindakan Sekolah ini.

\section{Pelaksanaan Tindakan}

Perlakuan supervisi klinis oleh peneliti terhadap kelompok guru kelas $\mathrm{V}$ Sekolah Dasar di enam SD binaan pada hari Senin tanggal 6 Agustus 2018, setelah pembelajaran usai yaitu pukul 13.00 WIB sampai pukul 15.00 WIB di SDN 006 Bengkulu Utara yang merupakan SD terbesar diantara enam SD binaan.

Pelaksanaan supervisi klinis dalam hal ini adalah melakukan pembinaan dan pembimbingan secara bersama-sama oleh peneliti terhadap kelompok guru kelas $\mathrm{V}$ di enam SD binaan sebanyak 11 orang. Tindakan supervisi klinis yang dilakukan khusus tentang pengelolaan Model Pembelajaran kooperatif pada guru kelas $\mathrm{V}$ yaitu meliputi : pemahaman isi standar proses, memilih metode dan pengelolaan kelompok peserta didik di kelas, ketrampilan bertanya, pelayanan individu, sumber belajar dan alat bantu mengajar, umpan balik dan penilaian, komunikasi dan interaksi, keterlibatan peserta didik, refleksi, hasil karya peserta didik dan hasil belajar peserta didik .

Pada akhir kegiatan supervisi klinis ini peneliti melakukan simulasi dengan guru-guru dengan langkah-langkah pembelajaran yang telah disusun bersama. Guru tidak segan-segan untuk bertanya dan mengemukakan pendapatnya kepada peneliti, sehingga ia merasa siap untuk mempraktikkan model pembelajaran kooperatif tersebut satu minggu berikutnya.

Dari sebelas Guru kelas V umumnya sangat tertarik, serius, dan santai, sebab hal ini biasanya Pengawas Sekolah datang langsung masuk kelas tanpa memberitahu dan langsung melakukan penilaian, kali ini Pengawas Sekolah datang dengan memberi pembinaan dan bimbingan dalam pengelolaan model pembelajaran kooperatif secara rinci.

Mata pelajaran yang dipilih oleh guru kelas $\mathrm{V}$ dalam penelitian ini adalah IPS tentang tokoh Pahlawan Pergerakan Nasional. Peneliti menunjukkan Standar Proses tentang pembelajaran. Guru diberi penjelasan tentang proses eksplorasi, elaborasi, dan konfirmasi. Peneliti memberikan pembinaan model pembelajaran kooperatif yang terdiri dari cara pengelolaan peserta didik yang bervariasi yaitu; secara klasikal, kelompok kecil, berpasangan dan 
individual. Selain itu anggota kelompok dibentuk beragam. Guru dalam memberikan pertanyaan berupaya terus, agar dapat memancing peserta didik, guru juga memberikan motivasi pelayanan individual kepada peserta didik, termasuk menggunakan berbagai sumber dan alat bantu mengajar, kemudian memberi umpan balik, ada komunikasi, hasil karya peserta didik dipajang, maupun guru selalu melakukan refleksi diri.

Guru selalu diberi kesempatan untuk mengemukakan pendapat atau ideidenya. Setelah kegiatan tersebut puas dan yakin dapat melaksanakan dengan baik, maka membuat kesepakatan waktu untuk pelaksanaan pembelajaran berpusat kooperatif tersebut yang diawali dari penyusunan RPP yang baik. Hasil kesepakatan antara guru-guru dengan peneliti bahwa, observasi terhadap pelaksanaan model pembelajaran kooperatif guru kelas V SD di enam SD binaan, akan dilaksanakan pada tanggal 13 sampai dengan tanggal 20 Agustus 2018 secara bergilir di kelas/sekolah masing-masing.

\section{Hasil Pengamatan}

Pengamatan yang dilakukan melalui dua hal, yaitu pengamatan oleh teman sejawat (Kepala Sekolah SDN 006 Bengkulu Utara) dalam melakukan proses tindakan pembimbingan materi Model Pembelajaran kooperatif pada kelompok guru kelas V SD di enam SD binaan yang dilaksanakan pada hari Kamis, 6 Agustus 2018 bertempat di SDN 006 Bengkulu Utara dan pengamatan yang dilakukan peneliti bersama teman sejawat (kepala sekolah masing-masing SD di enam SD binaan) terhadap RPP yang dibuat masing-masing guru kelas $\mathrm{V}$ SD dalam melakukan proses Model Pembelajaran kooperatif di kelas yang dilakukan sesuai jadwal pengamatan di berikut ini: Pada hari Senin tanggal 13 Agustus 2018 pelaksanaan pembelajaran 3 guru kelas V SDN 006 Bengkulu Utara, Selasa tanggal 14 Agustus 2018 pelaksanaan pembelajaran 1 guru kelas V SDN 011 Bengkulu Utara, Rabu tanggal 15 Agustus 2018 pelaksanaan pembelajaran 2 guru kelas V SDN 128 Bengkulu Utara, Kamis tanggal 16 Agustus 2018 pembelajaran 3 guru kelas V SDN 166 Bengkulu Utara, Jumat tanggal 18 Agustus 2018 pembelajaran 1 guru kelas V SDN 170 Bengkulu Utara, Senin tanggal 20 Agustus 2018 pembelajaran 1 guru kelas $V$ SD Muhammadiyah Arga Makmur. Pada umumnya proses pembelajaran yang dilakukan untuk mata pelajaran IPS tentang Tokoh Pergerakan Nasional. Guru melakukan proses pembelajaran menggunakan metode yang telah dipelajari yaitu Bermain Peran. Peserta didik dikelompokkan menjadi beberapa kelompok kecil untuk memerankan tokoh yang telah disepakati bersama. Secara berkelompok peserta didik berdiskusi membahas masingmasing perannya. Kegiatan menyenangkan, sudah muncul eksplorasi, elaborasi, dan konfirmasi. Dalam kegiatan eksplorasi, guru melibatkan peserta didik mencari informasi tentang sejarah, memfasilitasi terjadinya interaksi antar peserta didik serta antara peserta didik dengan guru, melibatkan peserta didik secara aktif. Proses elaborasi dilakukan dengan memberi tugas peserta didik untuk berani tampil di depan kelas dan memiliki rasa percaya diri serta tidak takut salah ingin melatih keberanian. Pada kegiatan konfirmasi, guru memberikan konfirmasi terhadap tampilan tiap kelompok kecil yang berisi penghargaan berupa pujian kepada kelompok yang sudah melaksanakan tugas tersebut. Guru memfasilitasi peserta didik untuk memperoleh pengalaman dalam mencapai kompetensi dasar.

Rekap skor rata-rata hasil pengamatan yang dilakukan teman sejawat terhadap proses pelaksanaan dan penilian hasil pembimbingan penyusunan model pembelajaran kooperatif secara kelompok Pada Akhir Siklus 1 guru kelas V SDN di enam SD binaan dapat dilihat pada kegiatan siklus 1, dan dapat dilihat juga pada tabel 4 adalah sebagai berikut:

Tabel 4. Observasi Siklus 1 


\begin{tabular}{|c|c|c|}
\hline No & Aspek Yang Dinilai & Skor \\
\hline (1) & $(2)$ & (3) \\
\hline 1. & Kemampuan menyampaikan tujuan & 4 \\
\hline 2. & Pemberian motivasi kepada peserta & 3 \\
\hline 3. & $\begin{array}{l}\text { Kemampuan memfasilitasi peserta } \\
\text { untuk mengungkapkan gagasan dan } \\
\text { pengalaman }\end{array}$ & 3 \\
\hline 4. & Penguasaan terhadap materi & 3 \\
\hline 5. & Kemampuan menyampaikan materi & 3 \\
\hline 6. & Relevansi materi dengan tujuan & 3 \\
\hline 7. & $\begin{array}{l}\text { Ketepatan penggunaan metode dan } \\
\text { teknik mengajar }\end{array}$ & 2 \\
\hline 8. & Pemanfaatan media pengajaran & 3 \\
\hline 9. & $\begin{array}{l}\text { Kemampuan memberikan contoh dan } \\
\text { ilustrasi }\end{array}$ & 3 \\
\hline 10. & $\begin{array}{l}\text { Kemampuan mengendalikan jalannya } \\
\text { diskusi atau presentasi tugas } \\
\text { individu/kelompok }\end{array}$ & 4 \\
\hline 11. & $\begin{array}{l}\text { Kemampuan berinteraksi dengan } \\
\text { peserta di dalam kelas }\end{array}$ & 3 \\
\hline 12. & $\begin{array}{l}\text { Penggunaan bahasa dalam } \\
\text { pembimbingan }\end{array}$ & 3 \\
\hline 13. & $\begin{array}{l}\text { Cara menjawab pertanyaan dan } \\
\text { memberi komentar dari peserta }\end{array}$ & 3 \\
\hline 14. & Pemberian umpan balik & 3 \\
\hline 15. & Kemampuan menyimpulkan isi materi & 3 \\
\hline \multicolumn{2}{|c|}{ Jumlah } & 76,7 \\
\hline \multicolumn{2}{|c|}{ Kategori } & Baik \\
\hline
\end{tabular}

Tabel 5. Pengamatan Siklus 1

\begin{tabular}{|c|c|c|c|c|}
\hline \multirow[t]{2}{*}{ Pengamat } & \multicolumn{2}{|c|}{$\begin{array}{c}\text { Skor } \\
\text { Pembimbi } \\
\text { ngan }\end{array}$} & \multirow{2}{*}{$\begin{array}{c}\text { Meni } \\
\text { ngkat } \\
\text { kan }\end{array}$} & \multirow{2}{*}{$\begin{array}{c}\text { Proe } \\
\text { sent } \\
\text { ase }\end{array}$} \\
\hline & $\begin{array}{c}\text { Aw } \\
\text { al }\end{array}$ & $\begin{array}{l}\text { Sikl } \\
\text { us I }\end{array}$ & & \\
\hline $\begin{array}{l}\text { Teman } \\
\text { Sejawat }\end{array}$ & 0 & 76,7 & 76,7 & $\begin{array}{c}76,7 \\
\%\end{array}$ \\
\hline
\end{tabular}

Keterangan :

Skor data pembimbingan dari $0<\mathrm{n} \leq$ 55 kurang maksimal, $55<\mathrm{n} \leq 75$ cukup, $76<\mathrm{n} \leq 90$ baik dan $90<\mathrm{n} \leq 100$ sangat baik terlihat bahwa skor pembimbingan untuk 11 guru kelas $V$ di enam SD binaan perolehan skor awal 0 dan perolehan skor pada sklus 1 adalah 76,7 atau masih dalam baik minimum atau belum maksimal dengan meningkatkan hasil perolehan skor 100. Dari seluruh aspek yang dinilai yang memperoleh skor 4 hanya pada aspek kemampuan menyampaikan tujuan.

Rekap skor rata-rata hasil pengamatan yang dilakukan oleh peneliti dan teman sejawat terhadap mutu pelaksanaan Model Pembelajaran Kooperatif oleh guru kelas V SD di enam SD binaan yang penulis kelompokkan menjadi 2 kelompok yaitu kelompok $A$ sebagai kelompok yang berkategori kurang dan kelompok B sebagai kelompok yang berkategori cukup serta dapat dilihat pada kegiatan siklus 1 dapat dilihat pada tabel 5 adalah sebagai berikut:

Tabel 6. Pelaksanaan Model Pembelajaran Kooperatif

\begin{tabular}{|c|c|c|c|}
\hline NO & INDIKATOR & $\begin{array}{c}\text { Kelom } \\
\text { pok A } \\
\text { (Kura } \\
\text { ng) }\end{array}$ & $\begin{array}{c}\text { Kelo } \\
\text { mpok } \\
\text { B } \\
\text { (Cuku } \\
\text { p) }\end{array}$ \\
\hline (1) & (2) & (3) & (4) \\
\hline \multirow[t]{5}{*}{$I$} & $\begin{array}{l}\text { Metode dan } \\
\text { pengelolaan Kelas }\end{array}$ & & \\
\hline & $\begin{array}{l}\text { 1. Pengelolaan } \\
\text { peserta didik } \\
\text { bervariasi }\end{array}$ & 2,2 & 2,7 \\
\hline & $\begin{array}{l}2 . \quad \text { Kegiatan } \\
\text { peserta didik } \\
\text { bervariasi }\end{array}$ & 2,1 & 2,7 \\
\hline & $\begin{array}{l}\text { 3. Peran } \\
\text { peserta didik dlm } \\
\text { kelompok kecil }\end{array}$ & 2,0 & 2,5 \\
\hline & $\begin{array}{l}\text { 4. Kelompok } \\
\text { belajar peserta } \\
\text { didik beragam }\end{array}$ & 1,8 & 2,8 \\
\hline \multirow[t]{4}{*}{ II } & $\begin{array}{l}\text { Ketrampilan } \\
\text { bertanya }\end{array}$ & & \\
\hline & $\begin{array}{l}1 . \quad \text { Guru } \\
\text { memberi } \\
\text { kesempatan } \\
\text { peserta didik }\end{array}$ & 2,0 & 2,8 \\
\hline & $\begin{array}{l}2 . \quad \text { Guru } \\
\text { mendorong peserta } \\
\text { didik bertanya }\end{array}$ & 2,1 & 2,7 \\
\hline & $\begin{array}{l}\text { 3. Peserta didik } \\
\text { berani bertanya }\end{array}$ & 2,1 & 2,7 \\
\hline \multirow[t]{2}{*}{ III } & $\begin{array}{l}\text { Pelayanan } \\
\text { individual }\end{array}$ & & \\
\hline & $\begin{array}{l}\text { 1. Ada program } \\
\text { pengembangan }\end{array}$ & 1,7 & 3,0 \\
\hline
\end{tabular}

Vol: 1, No: 1, Maret 2020 | 9| 


\begin{tabular}{|c|c|c|c|}
\hline & $\begin{array}{l}\text { 2. Penyelesaian } \\
\text { tugas peserta didik }\end{array}$ & 2.4 & 2.8 \\
\hline & $\begin{array}{l}\text { 3. Guru } \\
\text { melakukan tindak } \\
\text { lanjut }\end{array}$ & 2,0 & 3,0 \\
\hline \multirow[t]{4}{*}{ IV } & $\begin{array}{l}\text { Sumber belajar dan } \\
\text { alat bantu }\end{array}$ & & \\
\hline & $\begin{array}{l}1 . \quad \text { Gutu } \\
\text { menggunakan } \\
\text { berbagai sumber }\end{array}$ & 1,9 & 2,2 \\
\hline & $\begin{array}{l}2 . \quad \text { Guru } \\
\text { membuat alat } \\
\text { bantu }\end{array}$ & 2,0 & 2,5 \\
\hline & $\begin{array}{l}\text { 3. Guru trampil } \\
\text { mengunakan alat } \\
\text { bantu }\end{array}$ & 2,0 & 2,5 \\
\hline (1) & (2) & (3) & (4) \\
\hline \multirow[t]{4}{*}{$\mathbf{V}$} & $\begin{array}{l}\text { Umpan balik dan } \\
\text { penilaian }\end{array}$ & & \\
\hline & $\begin{array}{l}\text { 1. Guru } \\
\text { memberi umpan } \\
\text { balik menantang }\end{array}$ & 2,0 & 2,2 \\
\hline & $\begin{array}{l}2 . \quad \text { Guru } \\
\text { menggunakan } \\
\text { berbagai penilaian }\end{array}$ & 2,4 & 2,2 \\
\hline & $\begin{array}{l}\text { 3. Guru } \\
\text { memberi } \\
\text { penghargaan }\end{array}$ & 1,6 & 2,0 \\
\hline \multirow[t]{3}{*}{ VI } & $\begin{array}{l}\text { Komunikasi dan } \\
\text { Interaksi }\end{array}$ & & \\
\hline & $\begin{array}{r}\text { 1.Penggunaan } \\
\text { bahasa guru }\end{array}$ & 2,0 & 3,0 \\
\hline & $\begin{array}{l}\text { 2. Ada komunikasi } \\
\text { antara guru dan } \\
\text { peserta didik }\end{array}$ & 2,2 & 3,0 \\
\hline \multirow[t]{3}{*}{ VII } & $\begin{array}{l}\text { Keterlibatan } \\
\text { peserta didik }\end{array}$ & & \\
\hline & $\begin{array}{l}\text { 1.Peserta didik aktif } \\
\text { dlm pembelajaran }\end{array}$ & 2,1 & 3,0 \\
\hline & $\begin{array}{l}\text { 2. Guru memberi } \\
\text { kesempatan kpd } \\
\text { peserta didik }\end{array}$ & 2,2 & 3,0 \\
\hline \multirow[t]{2}{*}{ VIII } & Refleksi & & \\
\hline & $\begin{array}{l}\text { 1. Guru meminta } \\
\text { peserta }\end{array}$ & 1,9 & 1,8 \\
\hline \multirow[t]{3}{*}{ (1) } & (2) & (3) & (4) \\
\hline & $\begin{array}{l}\text { 2. didik menulis } \\
\text { kesan }\end{array}$ & & \\
\hline & $\begin{array}{l}\text { 3. Guru melakukan } \\
\text { refleksi diri }\end{array}$ & 2,1 & 2,2 \\
\hline \multirow[t]{2}{*}{ IX } & Hasil Karya & & \\
\hline & 1.Hasil karya & 2,1 & 2,0 \\
\hline
\end{tabular}

\begin{tabular}{|c|l|c|c|}
\hline & $\begin{array}{l}\text { peserta didik } \\
\text { dipajang }\end{array}$ & \\
\hline $\mathbf{X}$ & Hasil belajar & & \\
\hline & $\begin{array}{l}\text { 1.Hasil belajar } \\
\text { memenuhi KKM }\end{array}$ & 1,8 & 2,0 \\
\hline $\begin{array}{l}\text { 2.Peserta didik } \\
\text { percaya diri berani } \\
\text { tampil }\end{array}$ & 1,8 & 1,7 \\
\hline Jumlah skor & 50,3 & 62,8 \\
\hline
\end{tabular}

Keterangan :

- Perolehan skor Kategori Kurang (K) 0 - 55

- Perolehan skor Kategori Cukup (C) $56-75$

- Perolehan skor Kategori Baik (B) $76-90$

- Perolehan skor Kategori Sangat 91 - $100 \quad$ Baik (SB)

Diketahui bahwa skor mutu pelaksanaan model pembelajaran kooperatif guru kelas $\mathrm{V}$ yang dilakukan oleh teman sejawat (kepala sekolah masing-masing di enam SD binaan) adalah perolehan rata-rata nilai kelompok A adalah 50,3 sedangkan perolehan rata-rata nilai kelompok $\mathrm{B}$ adalah 62,8 dan rata-ratanya adalah 56,5 termasuk masih dalam kategori cukup minim nilai (kurang memuaskan).

Sedangkan hasil pengamatan oleh teman sejawat dalam pelaksanaan tindakan pembimbingan oleh peneliti tentang Model Pembelajaran Kooperatif Guru Kelas V Di enam SD binaan dapat dilihat pada tabel 8. Teman sejawat mengamati tindakan peneliti dalam membimbing dengan partisipasi aktif.

\section{Refleksi}

Dari hasil pengamatan yang telah dilakukan pada siklus 1 , dan untuk mengetahui apakah kemampuan guru dalam melaksanakan pembelajaran meningkat, maka hasil pengamatan pada akhir siklus 1 dibandingkan dengan data awal. Data awal untuk kelompok A ratarata 50 dan kelompok $B$ rata- rata 59 , maka rata-rata seluruh adalah 55 
(kategori kurang). Pada siklus 1 diperoleh data rata-rata untuk kelompok $A$ adalah 50,3 dan untuk kelompok B adalah 62,8 maka rata-rata 56,5. Data ini tampak dalam tabel 11 dan dalam gambar/diagram 2 dan 3 di bawah ini.

Tabel 7. Pengamatan Proses Model Pembelajaran Kooperatif Siklus 1

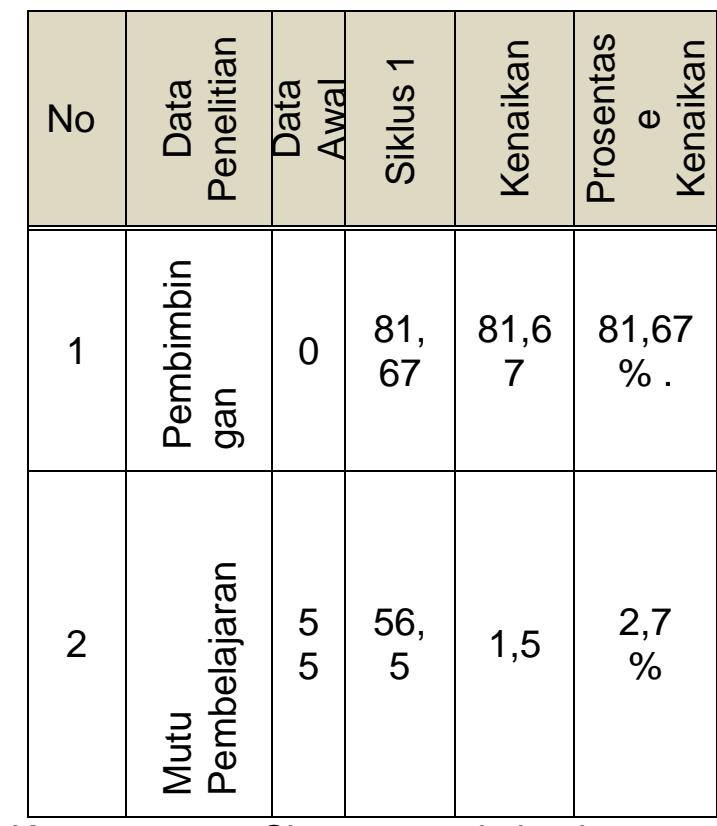

Keterangan: Skor maksimal mutu pembelajaran dan pembimbingan 100 .

Berdasarkan tabel 7 tersebut dapat diketahui bahwa skor nilai pembimbingan mencapai skor 81,67 atau $81,67 \%$ dan nilai skor mutu pembelajaran mengalami kenaikan 1,5 skor atau 2,7\%. Pada pembelajaran sebagian masih belum tampak pada elaborasi dan konfirmasi, serta nuansa pembelajaran belum maksimal. Sedangkan untuk pembimbingan ada yang belum nampak antara lain; penyampaian tujuan pembimbingan pada evaluasi pembelajaran, multi metode, memunculkan ide-ide guru. Berdasarkan hasil siklus 1 tersebut, maka akan dilakukan lagi dengan memenuhi semua pembimbingan, dengan harapan mutu pembimbingan model pembelajaran kooperatif pada guru kelas V SD di enam $\mathrm{SD}$ binaan akan meningkat.

\section{SIKLUS 2}

\section{Perencanaan Tindakan}

Setelah melakukan refleksi antara peneliti dengan kolaborator (teman sejawat/Kepala Sekolah masing-masing di enam SD binaan peneliti), maka peneliti merencanakan tindakan pada siklus ke 2. Peneliti melakukan koordinasi dengan kepala sekolah di enam SD binaan untuk menentukan tindakan pembimbingan pada siklus 2. Disepakati akan dilakukan pembimbingan secara individu dalam upaya peningkatan kemampuan guru kelas $\mathrm{V} S \mathrm{SD}$ dalam model pembelajaran kooperatif pada setiap guru sesuai dengan masalah yang dihadapi. Pelaksanaan mulai hari Senin tanggal 3 September sampai dengan hari Sabtu tanggal 10 September 2018.

Pada hari Senin tanggal 3 September 2018 pelaksanaan pembelajaran 3 guru kelas $V$ SDN 006 Bengkulu Utara, Selasa tanggal 4 September 2018 pelaksanaan pembelajaran 1 guru kelas $\mathrm{V}$ SDN 011 Bengkulu Utara, Rabu tanggal 5 September 2018 pelaksanaan pembelajaran 2 guru kelas V SDN 128 Bengkulu Utara, Kamis tanggal 6 September 2018 pembelajaran 3 guru kelas V SDN 166 Bengkulu Utara, Sabtu tanggal 8 September 2018 pembelajaran 1 guru kelas V SDN 170 Bengkulu Utara, Senin tanggal 10 September 2018 pembelajaran 1 guru kelas $V$ SD Muhammadiyah Arga Makmur.

Adapun Supervisi Pelaksanaan

Model Pembelajaran Kooperatif setiap guru kelas V SD di enam SD binaan, mulai hari Senin tanggal 1 Oktober samapi dengan 8 Oktober 2018 dengan jadwal sebagai berikut :

Pada hari Senin tanggal 1 Oktober 2018 pelaksanaan pembelajaran 3 guru kelas V SDN 006 Bengkulu Utara, Selasa tanggal 2 Oktober 2018 pelaksanaan pembelajaran 1 guru kelas V SDN 011 Bengkulu Utara, Rabu tanggal 3 Oktober 2018 pelaksanaan pembelajaran 2 guru kelas V SDN 128 Bengkulu Utara, Kamis tanggal 4 Oktober 2018 pembelajaran 3 guru kelas V SDN 166 Bengkulu Utara, Sabtu tanggal 6 Oktober 2018 pembelajaran 1 guru kelas V SDN 170 Bengkulu Utara, Senin tanggal 8 Oktober 2018 pembelajaran 1 guru kelas V SD 
Muhammadiyah Arga Makmur. Peneliti menyiapkan materi dan instrumen observasi pembimbingan dan observasi pembelajaran.

\section{Pelaksanaan Tindakan}

Pelaksanaan supervisi klinis atau pembimbingan tentang perbaikan proses pembelajaran ke arah model pembelajaran kooperatif oleh peneliti terhadap guru kelas V SD di enam SD binaan dilakukan secara individual dengan mempertimbangkan kelemahan yang ada pada tiap guru tersebut. Hal ini dilakukan mulai hari Selasa tanggal 3 September sampai dengan hari Rabu tanggal 10 September 2018 secara bergilir. Dengan diamati oleh teman sejawat, peneliti menyampaikan tujuan pembimbingan. Pembimbingan dengan mengkaji RPP secara bersama yang telah dimiliki, disesuaikan dengan standar proses, dan pedoman model pembelajaran Kooperatif yang di dalamnya terdapat penentuan alat peraga, metode, langkah-langkah pembelajaran, dan evaluasi hasil belajar, refleksi, tindak lanjut maupun pencapaian KKM yang dirumuskan.

Materi yang akan dipraktikkan pada siklus 2 adalah tentang kegiatan pembelajaran IPS: Tokoh Pahlawan Pergerakan Nasional, kemudian guru mengemukakan ide-ide melakukan simulasi pembelajaran. Guru terlihat gembira, dan merasa percaya diri dalam melakukan pembelajaran, kemudian menyusun langkah-langkah pembelajaran yang berisi eksplorasi, elaborasi, dan konfirmasi serta penjelasannya.

Mulai hari Selasa tanggal 1 Oktober sampai hari Sabtu tanggal 8 Oktober 2018, peneliti dan teman sejawat melakukan pengamatan terhadap guru kelas V secara bergilir dalam pembelajaran berpusat kooperatif. Masing-masing guru kelas $\mathrm{V}$ menyiapkan RPP hasil revisi di mejanya, beserta alat peraga yang digunakan. Dalam kondisi ini guru-guru terlihat lebih semangat, sehingga tertarik dengan alat-alat yang disediakan di atas meja, kemudian Guru mulai melakukan pembelajaran.
Peneliti dan teman sejawat duduk di kelas paling belakang dengan sikap tenang, serius sambil mengamati proses pembelajaran kooperatif . Peserta didik tampak gembira dan aktif di kelompoknya mengikuti pembelajaran yang berlangsung.

\section{Hasil Pengamatan}

Rata-rata skor hasil pengamatan oleh teman sejawat perihal proses pembimbingan model pembelajaran kooperatif pada individu guru kelas V SD masing-masing di enam SD binaan pada siklus 2 dapat dilihat pada tabel 11. Rata-rata skor hasil pengamatan adalah 81,7 atau masuk dalam kategori baik atau mampu melaksanakan pembelajaran berpusat kooperatif. Selengkapnya dapat dilihat pada lampiran. Semua aspek yang diniai dalam pembimbingan model pembelajaran kooperatif sudah memperoleh kategori baik namun belum ada aspek yang memperoleh rata-rata maksimal 4.

Tabel 8. Observasi Siklus 2.

\begin{tabular}{|r|l|c|}
\hline No & \multicolumn{1}{|c|}{ Aspek Yang Dinilai } & $\begin{array}{c}\text { Sk } \\
\text { or }\end{array}$ \\
\hline \hline$(1)$ & \multicolumn{1}{|c|}{$(2)$} & $(3)$ \\
\hline 1. & $\begin{array}{l}\text { Kemampuan menyampaikan } \\
\text { tujuan }\end{array}$ & 3,9 \\
\hline 2. & $\begin{array}{l}\text { Pemberian motivasi kepada } \\
\text { peserta }\end{array}$ & 3,2 \\
\hline 3. & $\begin{array}{l}\text { Kemampuan memfasilitasi } \\
\text { peserta untuk mengungkapkan } \\
\text { gagasan dan pengalaman }\end{array}$ & 3,1 \\
\hline 4. & Penguasaan terhadap materi & 3,1 \\
\hline 5. & $\begin{array}{l}\text { Kemampuan menyampaikan } \\
\text { materi }\end{array}$ & 3,6 \\
\hline 6. & Relevansi materi dengan tujuan & 3,1 \\
\hline 7. & $\begin{array}{l}\text { Ketepatan penggunaan metode } \\
\text { dan teknik mengajar }\end{array}$ & 3,1 \\
\hline 8. & Pemanfaatan media pengajaran & 3,6 \\
\hline 9. & $\begin{array}{l}\text { Kemampuan memberikan } \\
\text { contoh dan ilustrasi }\end{array}$ & 3,0 \\
\hline 10. & $\begin{array}{l}\text { Kemampuan mengendalikan } \\
\text { jalannya diskusi atau presentasi } \\
\text { tugas individu/ kelompok }\end{array}$ & 3,5 \\
\hline 11. & $\begin{array}{l}\text { Kemampuan berinteraksi } \\
\text { dengan peserta di dalam kelas }\end{array}$ & 3,0 \\
\hline 12. & $\begin{array}{l}\text { Penggunaan bahasa dalam } \\
\text { pembimbingan }\end{array}$ & 3,1 \\
\hline 13. & $\begin{array}{l}\text { Cara menjawab pertanyaan dan } \\
\text { memberi komentar dari peserta }\end{array}$ & 3,0 \\
\hline
\end{tabular}

P- ISSN : XXXX-XXXX E-ISSN : XXXX-XXXX Vol: 1, No: 1, Maret 2020 | 12 |

Available online at : http://journal.pdmbengkulu.org/index.php/semar 


\begin{tabular}{|r|l|r|}
\hline 14. & Pemberian umpan balik & 3,2 \\
\hline 15. & $\begin{array}{l}\text { Kemampuan menyimpulkan isi } \\
\text { materi }\end{array}$ & 3,0 \\
\hline Jumlah & 81, \\
\multicolumn{2}{|l|}{ Kategori } & 7 \\
\hline
\end{tabular}

Keterangan : $4=$ sangat baik , $3=$ baik, 2 = cukup, 1 = tidak baik

- Perolehan skor Kategori Kurang (K) $0-55$

- Perolehan skor Kategori Cukup (C) $56-75$

- Perolehan skor Kategori Baik (B) $76-90$

- Perolehan skor Kategori Sangat Baik (SB $91-100$

Tabel 9.Peningkatan pengamatan proses pembimbingan Siklus 2

\begin{tabular}{|c|c|c|c|c|}
\hline \multirow{2}{*}{ Pengamat } & \multicolumn{2}{|c|}{$\begin{array}{c}\text { Skor } \\
\text { Pembimbin } \\
\text { gan }\end{array}$} & $\begin{array}{c}\text { Meni } \\
\text { ngkat } \\
\text { kan }\end{array}$ & $\begin{array}{c}\text { Proes } \\
\text { en } \\
\text { tase }\end{array}$ \\
\cline { 2 - 4 } & $\begin{array}{c}\text { Sikl } \\
\text { us 1 }\end{array}$ & $\begin{array}{c}\text { Siklu } \\
\text { s 2 }\end{array}$ & tan \\
\hline \hline $\begin{array}{c}\text { Teman } \\
\text { Sejawat }\end{array}$ & $\begin{array}{c}76, \\
7\end{array}$ & 81,7 & 5 & $5 \%$ \\
\hline
\end{tabular}

Rata-rata hasil pengamatan proses pembelajaran guru kelas V SD di enam SD binaan pada siklus 2 adalah sebagai berikut : skor hasil pengamatan oleh peneliti dan teman sejawat pada pelaksanaan model pembelajaran kooperatif untuk guru kelas $\mathrm{V} S \mathrm{SD}$ kelompok $A$ adalah 63,5 , sedangkan ratarata pengamatan untuk kelompok $B$ adalah 81 , Rata-rata total menjadi 78 atau masuk dalam kategori baik. Hal tersebut berarti guru kelas V SD di enam SD binaan pada umumnya memiliki kemampuan dalam melaksanakan model pembelajaran kooperatif. Namun demikian untuk mengoptimalkan kemampuan guru tersebut perlu kontinuitas kegiatan pembimbingan oleh pengawas sekolah maupun kepala sekolahnya. Bukti dokumen pernyataan di atas selengkapnya dapat dilihat pada lampiran laporan penelitian tindakan sekolah ini.

\section{Refleksi}

Berdasarkan skor siklus 1 sampai siklus 2 (tampak dalam table 13 . Meningkatkan skor keberhasilan proses pembimbingan adalah 5 atau $6,5 \%$ dan meningkatkan skor keberhasilan mutu pembelajaran adalah naik 21,5 atau 38,5 $\%$. Data tersebut menunjukkan bahwa terdapat peningkatan perolehan skor proses pembimbingan maupun mutu pembelajaran meskipun belum maksimal.

Tabel 10. Rata-rata siklus 1 dan akhir siklus 2

\begin{tabular}{|c|c|c|c|c|c|}
\hline No & 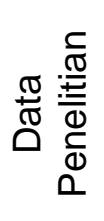 & $\frac{\bar{s}}{\frac{\bar{s}}{\bar{x}}}$ & $\begin{array}{l}N \\
\frac{N}{2} \\
\frac{\Sigma}{5}\end{array}$ & 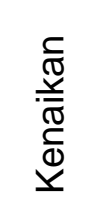 & 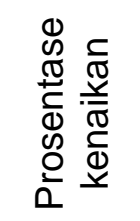 \\
\hline 1 & 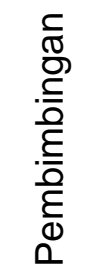 & $\begin{array}{c}76 \\
7\end{array}$ & 81,7 & 5 & $6,5 \%$ \\
\hline 2 & 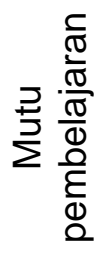 & 56,5 & 78 & 21,5 & $38,5 \%$ \\
\hline
\end{tabular}

Keterangan : Skor maksimal mutu pembelajaran dan pembimbingan 100

\section{Pembahasan}

Berdasarkan hasil tindakan pada siklus 1 dan 2 di atas dapat dirangkum ke dalam table 15 yaitu dari data awal, siklus 1 dan 2. Pada mutu pembimbingan terjadi meningkatkan dari data awal sampai akhir siklus 2 adalah 81,7 dan Pada mutu pembelajaran terjadi meningkatkan dari data awal sampai akhir siklus 2 adalah 78.

$$
\text { Penelitian Tindakan Sekolah }
$$
tentang meningkatkan mutu model pembelajaran kooperatif melalui penerapan supervisi klinis secara kelompok maupun secara individu oleh 
peneliti terhadap guru kelas $\mathrm{V}$ di enam SD binaan dapat dikatakan berhasil karena terjadi peningkatan skor pembimbingan dan skor pada mutu pembelajaran.

Indikator keberhasilan dari tindakan tersebut tidak hanya naiknya skor pengamatan, tetapi juga diikuti kesesuaian indikator keberhasilan yaitu:

1. Pembimbingan secara kelompok dan individu dilakukan secara intensif oleh Pengawas Sekolah, sehingga guru tidak merasa malu jika mengalami kesalahan.

2. Guru menyusun RPP sendiri dengan bimbinga

\section{Kesimpulan dan Saran Kesimpulan}

Penerapan Supervisi klinis dapat meningkatkan kemampuan guru kelas $\mathrm{V}$ SD dengan model pembelajaran kooperatif di enam SD binaan semester I tahun pelajaran 2018/2019" ternyata dapat terbukti kebenarannya. Hal ini dibuktikan dengan kenaikan skor hasil Proses supervisi klinis atau dalam hal ini pembimbingan dengan partisipasi aktif Pengawas Sekolah sebagai peneliti, dari kondisi awal belum dilaksanakan semula 0 setelah dilaksanakan dengan skor keberhasilan 76,7 pada siklus 1 , dan keberhasilan 81,7 pada siklus 2, sehingga total kenaikan keberhasilan $81,7 \%$ dan kenaikan skor hasil kegiatan pembelajaran dari 55 menjadi 56,5 pada siklus 1 , dan 56,5 menjadi 78 pada siklus 2. Total kenaikan sebesar $41,82 \%$.

\section{Saran}

Kepada rekan-rekan Kepala Sekolah, agar dalam melakukan pembinaan terhadap guru di daerah binaannya dapat menggunakan langkahlangkah penelitian ini. Teknik supervisi dilakukan bervariasi menurut kondisi guru, sehingga mudah mencapai hasil pembelajaran yang lebih baik. Perlu juga diubah pelaksanaan supervisi yang diartikan tidak hanya menilai guru secara langsung di dalam kelas, tetapi lebih dari itu, adalah meningkatkan kemampuan guru dalam penerapan model pembelajaran kooperatif . Sehingga dengan pendekatan ini, guru dalam melakukan pembelajaran merasa perlu dan penting untuk meningkatkan prestasi yang lebih baik. Pembimbingan yang sungguh-sungguh sudah selayaknya merupakan kewajiban tugas-tugas pokok dan fungsi Kepala Sekolah, sehingga mampu mencapai hasil sesuai dengan harapan. Kepada para Kepala Sekolah, agar cara pembinaan tersebut dapat diterapkan dalam membina guru-guru, sehingga seorang guru akan merasa senang, nyaman melaksanakan modelmodel pembelajaran di kelasnya, seperti model kelompok kecil yang sangat menyentuh anak dalam belajarnya, sehingga pada gilirannya, guru mampu meningkatkan mutu diri yang selanjutnya secara profesional meningkatkan prestasi belajar para peserta didik nya dan dapat meningkatkan mutu pendidikan pada umumnya sesuai dengan harapan orang tua, masyarakat dan bangsa Indonesia tercinta ini.

\section{Daftar Pustaka}

Asmawi Jamal Ma'mur, 2012. Tips Efektif Supervisi Pendidikan Sekolah, Yogjakarta: DIVA Press

Dirjen PMPTK 2010. Penelitian Tindakan Sekolah, Jakarta : Kemdiknas.

Akademik, Jakarta : Kemdiknas
Moh. User
Usman, 1995. Menjadi guru professional,
Jakarta.
Purwodarminto, WJS. Kamus Bahasa
Indonesia, Jakarta : Balai Pustaka.
Saifudin, 2007. Metode Penelitian,
Yogyakarta : Pustaka Pelajar
Suharsimi Arikunto, 2004. Prosedur
Penelitian. Jakarta : Rineksa Cipta.
Sugiyanto, 2010. Model-model
Pemeblajaran Inovatif. Surakarta:
Yuma Pressindo.
-----------, 2016. Permendiknas
nomor 22/2016, Jakarta:
Kemdikbud

